\title{
UNIONS AND PRODUCTIVITY IN THE PUBLIC SECTOR: A STUDY OF MUNICIPAL LIBRARIES
}

\author{
RONALD G. EHRENBERG, DANIEL R. SHERMAN, \\ and JOSHUA L. SCHWARZ*
}

\begin{abstract}
This paper develops and illustrates the use of two methodologies to analyze the effect of unions on productivity in the public sector. Although the methodologies are applicable to a wide variety of public sector functions, the focus of the paper is on municipal libraries because of the availability of relevant data. The empirical analysis, which uses 1977 cross-section data on 260 libraries, suggests that collective bargaining coverage has not significantly affected productivity in municipal libraries.
\end{abstract}

$\mathrm{T}$ HE traditional neoclassical view of unions asserts that although unions may benefit their members by creating noncompensating wage differentials, they also cause allocative efficiency losses and thus have a negative impact on the economy as a whole. Recently, however, this view has been challenged by Richard Freeman, James Medoff, and their associates at Harvard. ${ }^{1}$ Drawing on hypotheses put forth long ago by institutional economists, they have argued that unions may well increase productivity in a number of ways: by reducing

\footnotetext{
* Ronald Ehrenberg is a professor of economics and labor economics at Comell University and a research associate at the National Burcau of Economic Research. Daniel Sherman and Joshua Schwarz are graduate students at the New York State School of Industrial and Labor Relations. Cornell University. This research was supported by the National Science Foundation. An earlier version of the paper was presented at the Winter 1981 Econometric Soriety meetings. Without implicating them for what remains, the authors are grateful to Daniel Hanemesh and the discussants at those meetings for their comments on earlier drafts.
}

\footnotetext{
'A good, nontechnical treatment of their views is found in Richard B. Freeman and James L. Medoff, "The Two Faces of Unionism," Public Interest, No. 57 (Fall 1979), pp. 69-93.
}

turnover, increasing morale and motivation. and expanding formal and informal on-the-job training. Indeed, several of these scholars' econometric studies suggest that union/nonunion productivity differentials in the private sector are often positive.? To the extent that these results are generalizable. one must question whether unions in the private sector have actually had net adverse effects on efficiency.

No research, however, has been directed toward ascertaining the effect of unions on productivity in the public sector. This

\footnotetext{
'See, for example, Charles Brown and James L. Medoff, "Trade Unions in the Production Process," Journal of Political Economy, Vol. 86, No. 3 (June 1978), pp. 355-78, for evidence on manufacturing; Kim B. Clark, "The Impact of Unionization on Productivity: A Case Study," Industrial and Labor Relations Review, Vol. 33. No. 4 (July 1980). pp. 45I-69. for evidence on the cement industrv; and Steven $\mathrm{C}$. Allen, "Unionized Construction Workers are More Productive." mimeograph (Washington, D.C.: Center to Protect Worker Rights, 1979) for evidence on construction. Lest one conclude that these researchers always find that unions increase productivity in the private sector, see Marie Connerton, Richard B. Freeman, and James L. Medoff, "Productivity and Industrial Relations: The Case of Bituminous Coal." unpublished mimeograph (Cambridge, Mass.: Harvard University, 1979).
} 
neglect is understandable, since the concepts of output and productivity in the public sector are often not well defined, and the difficulties inherent in trying to measure productivity are consequently large. Nevertheless, the growing financial difficulties of state and local governments suggest that this important problem can no longer be ignored. Most studies of public sector wage determination have indicated that unions have had only modest effects on their members' compensation; ${ }^{3}$ studies of public-employee unions' effects on productivity are now required to complete our understanding of the effects these unions have had on municipal finances and service flows.

This paper therefore develops, and illustrates the use of, methodologies to analyze the effects of unions on productivity in the public sector. The methodologies discussed can be applied to a wide variety of public sector functions such as education, police, fire protection, and sanitation; but the focus here is on municipal libraries. This focus was chosen in part for expository reasons, since considerable effort has been devoted to conceptualizing productivity measures for libraries, and in part because relevant data are available for libraries. ${ }^{4}$ Thus, although the issue of productivity in muni-

'See, for example, Orley Ashenfelter, "The Effect of Unionization on Wages in the Public Sector: The Case of Firefighters," Industrial and Labor Relations Review, Vol. 24, No. 2 (January 1971), pp. $191-202$; Ronald G. Ehrenberg and Gerald S. Goldstein, "A Model of Public Sector Wage Determination," Journal of Urban Economics, Vol, 2, No. 2(July 1975), pp. 223-45; and Hirschel Kasper, "The Effects of Collective Bargaining on Public School Teachers' Salaries," Industrial and Labor Relations Review, Vol. 24, No. 1 (October 1970), pp. $57-72$.

4For previous discussions of library productivity, including its quality dimension, see Malcolm Getz, Public Libraries: An Economic View (Baltimore, Md., Johns Hopkins University Press, 1980); Karen Feldstein, The Economics of Public Libraries, unpublished Ph.D. dissertation (Cambridge, Mass.: Massachusetts Institute of Technology, 1977); F. W. Lancaster, The Measurement and Evaluation of Library Services (Washington, D.C.: Information Resources Press, 1977); and Ernst R. DeProspo, Ellen Altman, and Kenneth E. Beasley, Performance Measures for Public Libraries (Chicago, Ill.: Public Library Association, 1973). cipal libraries is important in its own right, we would stress the more general purpose of the paper.

\section{Analytic Framework}

Municipal libraries produce a variety of outputs, such as circulating books, periodicals, and other audio-visual materials; responding to requests for information and interlibrary loans; and providing reference facilities. These outputs can, in theory, be evaluated both quantitatively and qualitatively. One could, for example, simply count circulation figures or the number of information requests, but a more sophisticated valuation of library output would focus on such questions as "What proportion of information requests were answered correctly?" or "How long did the typical borrower have to wait for a book that he or she wanted?"

For now, we shall ignore the fact that libraries can be thought of as multiproduct firms, and throughout the paper, because of data limitations, we are forced to ignore the quality dimension of the services libraries provide. Instead, we treat library output (Q) as a single variable. The community demand function for library services can then be specified as:

$$
D=D\left(P \mid V_{1}, V_{2}\right)
$$

Here, $P$ is the "price" the community must pay for a unit of library services; other things equal, the higher the price, the fewer the library services demanded. The position of the demand curve will depend on both community income or wealth, with higher income areas demanding more library services, and on the size of the community $\left(V_{1}\right)$. It will also depend on the community's "tastes" for library services $\left(V_{2}\right)$. More highly educated communities, for example, may demand more library services, as may communities with a relatively large proportion of school-aged children.

The second element of our model is the following production function for library services:

$$
Q=F\left(K, L \mid V_{3}, U\right) .
$$


Here we have treated output, capital $(K)$, and labor $(L)$ as single variables. The capital stock includes the library's entire stock of materials as of the current period. $V_{3}$ is a vector representing those community variables that affect the position or shape of the production function. One early study, for example, found that two-thirds to threequarters of all library users lived within one mile of a library. ${ }^{5}$ This finding suggests that, other things equal, increases in popu. lation density, which facilitate locating branch libraries within a short distance of all individuals in the community, increases the flow of library services.

The production function for library services may also be a function of whether the library's employees are represented by a union $(U)$. As noted by Freeman and Medoff, unionization may increase productivity by inducing reductions in turnover, increases in morale and motivation, and increases in formal and informal onthe-job training. If one examines the kinds of contract provisions that library unions have tried to win from municipal employers, one will recognize many of them as the "enlightened" personnel practices widely accepted in the private sector as leading to increases in productivity. Examples here include the standardization of entrance qualifications and examinations, the recognition of seniority rights, and the policy of encouraging promotion from within, as well as the establishment of equal opportunity and pay for men and women. Of course, plausible arguments can be made that some of these provisions, especially those that limit management flexibility, may well reduce productivity. The net effect of these provisions on library productivity is an open question. ${ }^{6}$

\footnotetext{
'Bernard Berelson. The Library's Public (New York: Columbia University Press, 1949).

${ }^{6}$ For a discussion of the ways in which unions may influence productivity in libraries, see, for example, Herbert Biblo, "Librarians and Trade Unionism: A Prologue," and Marilyn A. Oberg, Mary Blackburn, and Joan Dible, "Unionization: Costs and Benefits to the Individual and to the Library," both in Margaret Chaplan, ed., Employee Organization and Collective Bargaining in Libraries, a special issue of Library Trends, Vol. 25. No. 2(October 1976), pp. 423-33 and 435-49, respectively.
}

In addition, the unionization of library employees may reduce productivity if it places limits on library management's ability to substitute among factors of production in its decision making or if unionization forces management to devote additional resources to contract negotiations and to the resolution of grievances. Unioninduced increases in labor costs may also lead to a reduction in the hours that a library is open, which in turn may reduce library output, since some potential "customers" may find their usage of the library restricted by the reduced hours. ${ }^{7}$ Finally, libraries are service organizations in which unionized employees interact directly with library users to produce library output. To the extent that unionization influences the nature of these interactions, library output may be altered. Of key concern in this analysis is the net impact of all these effects of unions on the production function.

A library's stock of capital depends on its stock of capital in the preceding period $\left(K_{-1}\right)$, its investment in new capital $(I)$, and the rate at which its previous stock of capital depreciates $(\delta)$. The latter depends on the age distribution of the library's books (in the main, books are used most heavily in the initial years following their purchase) and the resources the library devotes to maintaining its collection and avoiding theft. The function for the stock of capital is thus:

$$
K=I+(1-\delta) K_{-1} .
$$

\footnotetext{
${ }^{7}$ Getz, in Public Libraries, pp. 28-55, (chapter 2) presents some evidence, for a sample of large municipal libraries, that increases in labor costs are associated with reductions in hours of library operations and that reductions in library hours are associated with lower library circulation per capita. The latter relationship is not statistically significant, however.

We should note that unions may also affect library employees' hours of work, as well as the hours of library operation. If the former occurs, it may distort the estimates of union effects on annual salaries and productivity, which are reported in the next section. We have no data on library employees' hours of work, and so we do not address this problem in the text. Our impression, however, is that unions have not significantly reduced hours of work in the public sector, except in the case of firefighters. Hence, our omission of an hours measure is not likely to be a serious one.
} 
The costs incurred by a library are pri. marily for labor, new acquisitions, and maintaining the library's collection and buildings. Let $W$ be the cost per unit of labor. We assume that this cost does not vary with the number of library employees hired; that is, the library does not have any monopsony power. Let $m$ be the per-unit cost of maintaining the collection and $c$ the cost of new materials. The total costs the library incurs are thus given by:

$$
C=W L+c I+m K_{-1} .
$$

To the extent that unions are successful in increasing their members' wages, of course, $W$ will be an increasing function of $U$.

The assumption that cost minimization occurs in the public sector is sometimes challenged by those who argue that there are no natural forces in that sector to encourage cost minimization similar to the competitive pressures on profit-making firms in the private sector. Given the financial pressures faced by municipalities since the mid-1970s, however, many local government officials probably would not support this challenge; we therefore maintain a hypothesis of cost minimization. ${ }^{8}$ The average cost function for library services is obtained by minimizing costs (Equation 4), subject to the production-function and capital-stock constraints (Equations 2 and 3 , respectively). The average cost function, $A C$, is thus given by the following:

(5) $A C=A C\left(Q \mid W, c, m, V_{3}, \delta, K_{-1}, F, U\right)$.

If the underlying library production function exhibits constant (decreasing or increasing) returns to scale, average costs will be constant (increasing with output or decreasing with output).

The average cost curve represents the price to the library of producing different levels of library services. Given the demand curve, $D$, the equilibrium level of library services, $Q^{*}$, is assumed to be obtained by

${ }^{8}$ For a discussion of alternative models of public sector decision making, see the papers in Daniel S. Hamermesh, ed., Labor in the Public and Nonprofit Sectors (Princeton, N.J.: Princeton University Press, 1975). setting demand equal to average costs. From Equations 1 and 5, this equilibrium level can be expressed as the reduced-form equation:

$$
Q^{*}=G\left(V_{1}, V_{2}, V_{3}, W, c, m, \delta, K_{-1}, F, U\right) .
$$

Obviously, any factor that shifts the demand curve up will increase output, whereas any factor that shifts the average cost curve up will reduce output. The important point to note here is that observed output is determined by both demand and cost factors.

The effects of unions on service flows operate via both their effects on wages and their effects on the production function (Equation 2). If unions do increase the wages of library employees, this increase should shift the average cost curve up and reduce output. If unions increase (decrease) the level of output associated with any given input levels (for the reasons discussed earlier), this change will shift the average cost curve down (up), thereby increasing (decreasing) output.

Equation 6 provides a simple framework that can be used to estimate the effects of unions on productivity. If cross-section data on library services, on the demand and cost variables, and on unionization can be obtained, the model can be estimated. The coefficient of the unionization variable in this model would represent the net effect of library unions on productivity. If one were to estimate Equation 6 without the wage variable, however, the coefficient of the unionization variable would capture both the net effect of unions on the production function for library services and the effect of union-induced wage gains on average costs and, hence, on output. Of course, if coverage by a collective bargaining agree. ment is endogenously determined, estimation of Equation 6 by ordinary least squares would not necessarily lead to consistent estimates of the union effects.

\section{Estimating the Model}

In 1977, the International City Management Association (ICMA) conducted a survey of municipal public libraries in cities with populations of at least 50,000 . The 
survey, the results of which were made available to us by ICMA, collected data on library revenues and expenditures, employment and wage scales for different categories of library employees, the number of books in each library, and various measures of library usage, including circulation and the number of borrowers, information requests, and interlibrary loans. These data are supplemented here with data on the socioeconomic characteristics of cities, obtained from the 1977 City and County Databook, and with data, obtained from a mail survey by the authors, on whether any library employees in each municipality were covered by a collective bargaining agreement in 1977 .

These data permit the estimation of equations of the following form:

$$
\begin{aligned}
& \quad Z_{K i}=\sum_{j} B_{K j} V_{j i}+\gamma_{K} u_{i} \\
& +\varepsilon_{K i}, \text { where } K=1,2, \ldots .8,
\end{aligned}
$$

for a sample of 256 municipal libraries. ${ }^{9}$ Equation 7 is a reduced-form version of the library output equation, Equation 6, derived above. The output measures used are the number of information requests $\left(Z_{1}\right)$, borrowers $\left(Z_{2}\right)$, and interlibrary loans $\left(Z_{3}\right)$; the total circulation $\left(Z_{4}\right)$; and book and periodical circulation $\left(Z_{5}\right)$ - each expressed as a per capita measure and in natural logarithm form. We also use several measures of service flows per borrower, all in natural logarithm form: interlibrary loans per borrower $\left(Z_{6}\right)$, total circulation per borrower $\left(Z_{7}\right)$, and book and periodical circulation per borrower $\left(Z_{8}\right)$.

$V_{i}$ represents those variables expected to influence library output, from either the demand or the cost sides of the model. The demand side is represented by a set of variables assumed to be related to a community's preference for library services. These variables include several measures of the age, race, and sex distributions of the population (percentages of the population older than age eighteen $\left(V_{16}\right)$, older than age

\footnotetext{
9Some of these data have been published in the 1978 Municipal Yearbook (Washington, D.C.: International City Management Association, 1978). The number of observations varies across equations because of the nonreporting of data.
}

sixty-five $\left(V_{17}\right)$, nonwhite $\left(V_{18}\right)$, and female $\left.\left(V_{19}\right)\right)$. We hypothesize, as previous studies have suggested, that school-aged children are more likely to use municipal public libraries, the elderly less likely (because of health limitations), nonwhites less likely (because historically they have made less use of municipal services), and females more likely (because of lower labor-force participation rates). Community preferences for library services are also assumed to be positively related to the median education level in the community $\left(V_{20}\right)$ and to the percentage of employees in the community who are employed in education $\left(V_{21}\right)$. The community's ability to pay, as measured by median family income $\left(V_{z 2}\right)$, is also assumed to influence the demand for library services.

The cost side is captured first by several organizational variables. Libraries that are separate municipal departments $\left(V_{1}\right)$ may benefit from being "managed" by municipal employees whose preoccupation is solely with the individual library, whereas those that are part of a larger library system $\left(V_{11}\right)$ may benefit from economies of scale in certain library functions (such as ordering). The cost side is also captured by library volumes per capita $\left(V_{\mathrm{I} 2}\right)$, which is a proxy for the lagged capital stock, and by several demographic variables (city population, $V_{111}$; population change, $V_{18}$ and $V_{14}$; and population density, $V_{15}$ ). These demographic variables may reflect economies of scale $\left(V_{10}\right)$, the depreciation rate of the stock of library materials $\left(V_{13}, V_{14}\right)$, or the cost of providing library services $\left(V_{15}\right) .^{10}$

Collective bargaining coverage is captured by a dichotomous variable, $u_{i}$, that

\footnotetext{
10Several weaknesses in our data base should be apparent. First, we are forced to use the current stock of library volumes as a proxy for the lagged capital stock (although preliminary analysis suggests that omitting this variable does not substantially affect our results). Second, in the absence of data on the age distribution of books in a library's collection or data on the resources devoted to maintenance of the collection, we use data on the growth rate of population in the city as a proxy for the depreciation rate of the collection, assuming that more rapidly growing cities have "younger" collections. Third, we have no data on other durable capital inputs, such as the number or size of library buildings.
} 
indicates whether any library employees in the municipality were covered by a collective bargaining agreement in 1977. Approximately one-third of the libraries in the sample had some employees covered by an agreement in 1977.

The structure and scope of collective bargaining coverage for library employees is, of course, much more complicated than this simple dichotomous variable would suggest. ${ }^{11}$ In small cities, library employees are more likely to belong to unions that also represent other municipal employees, whereas in larger cities, library employees sometimes have their own bargaining units. Where organized, professional library employees tend to be included with nonprofessional employees in the same unit, but sometimes only the nonprofessional employees are covered by a collective bargaining agreement. Clearly, the structure of collective bargaining influences the effect that unions have on productivity. Library unions restricted to professional employees may well be more concerned with the quality of services provided than unions restricted to nonprofessional employees or unions that cover nonlibrary employees as well. These unions may focus more on winning improved wages and working conditions and be less concerned about the quantity or quality of library services provided.

Similarly, the ability of a library union to win contract demands is likely to depend at least in part on the percentage of library employees who are unionized, not simply on whether any employees are covered by a collective bargaining agreement. Although it is clear in hindsight that our mail survey should have sought to obtain more information on the structure and scope of collective bargaining, the survey was unfortunately restricted to obtaining data on the dichotomous variable, $u_{i}$.

\footnotetext{
"Some of the discussion of the structure of collective bargaining for library employees that follows is drawn from Theodore L. Guyton, Unionization: The Viewpoint of Librarians (Chicago, Ill.: American Library Association, 1975), pp. 36-45. Guyton's data, however, are for a period earlier than the one we analyze.
}

In this initial specification, we have excluded library employees' wages from the right-hand side of Equation 7; later we relax this restriction. Because of this exclusion, the coefficients of the unionization variable will capture the net effects of both collective bargaining on the production function for library services and union-induced wage gains on average costs and, hence, output. ${ }^{12}$

Estimates of Equation 7 appear in Table $1 .{ }^{13}$ In the vector of variables other than unionization, several of the variables influence library output in a manner consistent with our a priori predictions. For example, whenever the relationships are statistically significant, increases in the school-aged population (decreases in $V_{16}$ ), the aged population $\left(V_{17}\right)$, median education level $\left(V_{20}\right)$, the proportion of the population employed in education $\left(V_{21}\right)$, and community income $\left(V_{22}\right)$ all increase various measures of library output. Some measures expected to influence output (such as the proportion of the population that is female, $\left.V_{19}\right)$ are always insignificant, however. Finally, contrary to our expectations, an increase in population density $\left(V_{15}\right)$ is associated with fewer borrowers and smaller circulation levels, and an increase in the aged population is associated with higher circulation levels. ${ }^{14}$

\footnotetext{
${ }^{12} \mathrm{We}$ exclude wages initially because it is likely that the same forces that influence library employees' wages also influence library output, and thus the inclusion of wages on the right-hand side of the equation would lead to simultaneous-equations bias. In the absence of a set of variables that can be used to identify the wage and output equations, one can think of Equation 7 as a reduced-form equation in which the coefficient of each explanatory variable, including unionization, reflects both the variable's direct effect on output and its indirect effect-the latter operating through the effect of the variable on wages and the effect of wages on output.

${ }^{19}$ The number of observations used to estimate the equations in Table 1 , and Table 2 below, varies between 161 and 256 due to the nonreporting of data on the dependent variables. Since most of the estimated union/nonumion differentials prove to be zero, we do not worry about whether nonrandom differences in the various samples affect the pattern of results.

${ }^{14} \mathrm{Getz}$, in Public Libraries: An Economic View, pp. $87-93$, finds a similar negative relationship between density and library output in his study of branch libraries in New York City. He argues that population density may be a proxy for the rental cost of structures.
} 
Table 1. Determinants of Productivity in Municipal Libraries in 1977.

(absolute value $t$-statistics in parentheses)

\begin{tabular}{|c|c|c|c|c|c|c|c|c|}
\hline Variables & $Z_{1}$ & $Z_{2}$ & $Z_{9}$ & $Z_{4}$ & $Z_{5}$ & $Z_{6}$ & $Z_{7}$ & $Z_{8}$ \\
\hline $\mathrm{C}$ & $-5.010(1.6)$ & $-1.551(1.2)$ & $-3.020(0.8)$ & $.937(0.9)$ & $2.210(1.9)^{* *}$ & $-1.260(0.3)$ & $2.520(1.8)^{* *}$ & $3.940(2.4)^{* *}$ \\
\hline$v_{1}$ & $-.385(1.8)^{* *}$ & $-.189(2.1)^{*}$ & $.221(0.9)$ & $-.150(2.1)^{*}$ & $-.239(2.8)^{*}$ & $.415(1.6)$ & $.040(0.4)$ & $-.082(0.7)$ \\
\hline$V_{10}{ }^{a}$ & $1.930(3.2)^{*}$ & $.140(1.0)$ & $.238(0.6)$ & $-.078(0.7)$ & $-.088(0.7)$ & $.008(0.2)$ & $-.215(1.4)$ & $-.261(1.6)$ \\
\hline$v_{11}$ & $-.199(1.5)$ & $.042(0.7)$ & $-.438(2.3)^{*}$ & $.051(1.1)$ & $-.014(0.3)$ & $-.460(2.7)^{*}$ & $.010(0.2)$ & $-.180(0.3)$ \\
\hline$V_{12}$ & $.096(2.0)^{*}$ & $.092(4.4)^{*}$ & $.357(5.9)^{*}$ & $.141(8.2)^{*}$ & $.137(6.1)^{*}$ & $.266(4.2)^{*}$ & $.050(2.1)^{*}$ & $.021(0.7)$ \\
\hline$V_{13}{ }^{6}$ & $.281(2.0)^{*}$ & $.121(2.0)^{*}$ & $-.149(0.8)$ & $.042(0.8)$ & $-.287(5.0)^{*}$ & $-.269(1.5)$ & $-.082(1.2)$ & $-.384(5.0)^{*}$ \\
\hline$v_{1 \cdot 1}^{b}$ & $-.294(0.5)$ & $-.027(0.0)$ & $.995(1.2)$ & $.242(1.1)$ & $.719(2.9)^{*}$ & $-.946(1.1)$ & $.281(0.9)$ & $.814(2.5)^{\star}$ \\
\hline$v_{15}^{1.6} b$ & $.001(0.0)$ & $-.015(1.7)^{* *}$ & $-.020(0.7)$ & $-.019(2.5)^{*}$ & $-.024(3.0)^{*}$ & $-.004(0.2)$ & $-.004(0.4)$ & $-.009(0.8)$ \\
\hline$V_{16}^{b}$ & $.522(0.3)$ & $-.453(0.5)$ & $-5.360(2.2)^{*}$ & $-.861(1.2)$ & $-1.490(1.9)^{* *}$ & $-5.070(2.0)^{*}$ & $-.454(0.5)$ & $-1.120(1.1)$ \\
\hline$V_{17}^{b}$ & $-1.780(0.8)$ & $-.433(0.4)$ & $-.551(0.2)$ & $1.650(2.0)^{*}$ & $1.440(1.3)$ & $-.093(0.0)$ & $2.170(2.0)$ & $3.790(2.5)^{*}$ \\
\hline$V_{1 x^{b}}^{b}$ & $17.600(2.6)^{*}$ & $-.524(1.9)^{* *}$ & $-2.390(0.9)$ & $-.417(1.8)^{* *}$ & $-.064(0.2)$ & $-1.870(2.2)^{*}$ & $.119(0.4)$ & $.613(1.7)^{* *}$ \\
\hline$V_{19}^{10}$ & $.034(0.7)$ & $.012(0.6)$ & $.048(0.8)$ & $-.009(0.5)$ & $-.023(1.2)$ & $.034(0.6)$ & $-.021(1.0)$ & $-.039(1.5)$ \\
\hline$V_{210}$ & $.111(1.0)$ & $.010(0.2)$ & $-.079(0.6)$ & $.079(2.1)^{*}$ & $.072(1.7)^{* *}$ & $-.090(0.7)$ & $.070(1.4)$ & $.053(0.9)$ \\
\hline$v_{21}^{-11}$ & $-.016(1.0)$ & $.095(1.6)$ & $.030(1.7)^{* *}$ & $.015(3.0)^{*}$ & $.016(2.8)^{*}$ & $.020(1.1)$ & $.005(0.8)$ & $.010(1.3)$ \\
\hline$V_{y g}^{-1}$ & $.092(2.5)^{*}$ & $.025(1.7)^{* *}$ & $.062(1.4)$ & $.039(3.1)^{*}$ & $.005(3.5)^{*}$ & $.038(0.8)$ & $.014(0.8)$ & $.030(1.5)$ \\
\hline$u^{--}$ & $.185(1.4)$ & $.019(0.3)$ & $.288(1.7)^{* *}$ & $-.049(1.0)$ & $.002(0.0)$ & $.280(1.6)$ & $-.059(0.9)$ & $-.010(0.2)$ \\
\hline $\mathrm{R}^{\prime \prime}$ & .233 & .231 & .293 & .477 & .470 & .219 & .106 & .208 \\
\hline$N$ & 213 & 252 & 255 & 256 & 215 & 251 & 252 & 211 \\
\hline
\end{tabular}

a The coefficient has been multiplied by $1,000,000$.

${ }^{b}$ The coefficient has been multiplied by 100 .

* Coefficient is statistically significant at the .05 level in a two-tailed test.

**Coefficient is statistically significant at the .10 level in a two-tailed test.

Legend:

$Z_{1} \quad$ The number of information requests per capita.

$Z$. $\quad$ The number of borrowers per capila.

$Z_{3} \quad$ The number of interlibrary loans per capita.

$Z_{1} \quad$ The total circulation per capita.

$Z_{5} \quad$ Book and periodical circulation per capita.

$Z_{i \mathrm{i}} \quad$ The number of interlibrary loans per borrower.

$Z_{7} \quad$ The total circulation per borrower.

$Z_{\aleph} \quad$ Book and periodical circulation per borrower.

$C$ An intercept term.

$V_{1} \quad$ l=library is a separate department: $0=$ otherwise.

$V_{11} \quad 1975$ city population.

$V_{11} \quad$ l=library is part of a larger system; $0=$ otherwise.

$V_{12} \quad$ The number of library volumes per capita.
$\begin{array}{ll}V_{13} & \text { Percent population change in the city, 1960-70. } \\ V_{11} & \text { Percent population change in the city, 1970-75. } \\ V_{15} & 1975 \text { population density in the city. } \\ V_{11} & 1975 \text { percentage of the city population older than age } 18 . \\ V_{17} & 1975 \text { percentage of the city population older than age } 65 .\end{array}$

1970 median education level in the city.

1970 percentage of employees in the city employed in education.

1969 median family income level in the city.

l = a municipality in which any library employees were covered by a collective bargaining agreement in $1977 ; 0=$ a municipality in which no library employees 
Our primary interest is in the collective bargaining variable, $u$. It is strikingly apparent that this variable is insignificantly related to most of the output measures. Only interlibrary loans $\left(Z_{3}\right.$ and $\left.Z_{6}\right)$ are even marginally related to the presence of a union, as municipalities whose library employees were covered in 1977 by an agreement had, other things equal, some 33 percent $\left(e^{.228}-\right.$ 1) more interlibrary loans per capita than municipalities with nonunion libraries. ${ }^{15}$ Since such loans are hardly a major function of municipal libraries, the overall effect of unions on municipal library output is quite small.

The coefficients of the collective bargaining variable in Table 1 capture the sum of the effects of collective bargaining on the production function for library services and of the effects of union-induced wage gains on average costs and, hence, on output. Estimates of the effect of library employees' unions on their members' wages are also of interest in themselves. As noted previously, other things equal, a union-induced wage gain will reduce output; thus, if library unions have raised their members' wages, the productivity of those employees would have to have increased to explain the finding in Table 1 that library output is not af-

with more densely populated areas having higher rental rates. If this relationship does exist, the average cost of library services may well be higher in those areas, which would lead to a lower level of library services. A negative relationship between population density and library output, therefore, may well be consistent with our model. The positive relationship between circulation and the proportion of the population that is aged may reflect the greater leisure time of this group that is associated with retirement.

${ }^{15}$ One might be tempted to argue that this finding is a statistical artifact of our lumping together in the sample libraries that are quite heterogeneous in functions. In particular, if central-city libraries with a large number of volumes per capita $\left(V_{12}\right)$ are primary suppliers of interlibrary loans and also tend to be unionized, the unionization variable may at least partially be capturing the effects of city size and library type. In an attempt to control for this possibility, we reestimated Equation 7 by restricting the sample to cities with populations of under 100,000 . Although the statistical significance of the union coefficients in the interlibrary-loan equations declined, the point estimates remained virtually identical to those reported in Table 1 . Thus, this line of explanation does not appear to be correct. fected by the presence of a union agreement.

Estimates of the determinants of library employees' wages, based on existing models of public sector wage determination, are presented in Table 2 for four categories of library employees. ${ }^{16}$ Since the demand for library employees is derived from the demand for library output and since the supply of potential applicants to the library also influences public sector wages and average library costs, the vector of explanatory variables in Table 2 is, not surprisingly, identical to that in Table $1 .{ }^{17}$ What is remarkable is (1) how poorly library employees' wages can be explained by these data (given the success of previous studies of public sector wage determination) and (2) the strong indication that collective bargaining has not significantly affected the wages of library employees. ${ }^{18}$ Given the results in Table 1 , it follows that collective bargaining in municipal public libraries has, on average, had no substantial effect on either the wages or productivity of library employees.

How sensitive are these findings to the estimation methods used? Columns 1 of Tables 3 and 4 summarize the estimated output (Table 1) and wage (Table 2) differentials obtained so far. Columns 2 of these tables show the estimated differentials that result from (1) dropping the assumption that collective bargaining coverage influ-

\footnotetext{
${ }^{16}$ See, for example, Ehrenberg and Goldstein, "A Model of Public Sector Wage Determination.'

${ }^{17} \mathrm{An}$ additional variable that should, in principle, enter only the wage equation is some measure of wages in occupations that represent possible alternatives for library employees. Proxies for such a measure-average hourly earnings in manufacturing in the city and average monthly eamings of municipal employees in the city-never proved significant. however, and thus were excluded from the analyses reported in the text.

${ }^{18}$ Our failure to find any significant wage gains associated with collective bargaining for library employees may reflect two different kinds of wage spillover effects. The wages of nonunion library employees may be affected by the wages of other municipal employees who are unionized; or their wages may be affected by the wages of unionized library employees in other geographic areas. See Ehrenberg and Goldstein, "A Model of Public Sector Wage Determination," for a discussion of occupational and geographic spillovers of union wage gains in the public sector.
} 
Table 2. Determinants of Salaries of Employees in Municipal Libraries in 1977.

(absolute value $t$-statistics in parentheses)

\begin{tabular}{|c|c|c|c|c|c|c|c|c|}
\hline Variables & $S_{\text {I }}$ & $S_{2}$ & $S_{y}$ & $S_{4}$ & $S_{5}$ & $S_{6}$ & $S_{7}$ & $S_{8}$ \\
\hline C. & $8.340(8.0)^{*}$ & $8.910(7.4)^{*}$ & $8.070(6.8)^{*}$ & $8.300(7.0)^{*}$ & $8.370(6.6)^{*}$ & $7.871(5.8)^{*}$ & $8.360(7.1)^{*}$ & $9.060(7.7)^{*}$ \\
\hline$V_{1}$ & $-.034(0.5)$ & $-.039(0.5)$ & $-.005(0.1)$ & $.001(0.0)$ & $.021(0.3)$ & $.011(0.1)$ & $.007(0.1)$ & $-.046(0.5)$ \\
\hline$V_{10}{ }^{a}$ & $.008(.08)$ & $.471(3.9)^{*}$ & $-.001(0.0)$ & $.030(2.7)^{*}$ & $.003(0.2)$ & $.026(1.9)^{* *}$ & $.127(0.5)$ & $1.070(4.2)^{*}$ \\
\hline$v_{11}^{10}$ & $.036(0.8)$ & $.041(0.8)$ & $.022(0.4)$ & $.060(1.2)$ & $.037(0.7)$ & $.099(1.7)^{* *}$ & $-.011(0.2)$ & $.390(0.8)$ \\
\hline$V_{12^{\prime \prime}}$ & $-.478(0.3)$ & $2.160(1.1)$ & $-.647(0.4)$ & $2.230(1.3)$ & $-.069(0.3)$ & $1.140(0.5)$ & $-1.240(0.7)$ & $-.222(0.1)$ \\
\hline$V_{13}{ }^{a}$ & $.536(0.0)$ & $2.950(0.1)$ & $.981(0.0)$ & $2.500(0.1)$ & $-84.900(1.5)$ & $-66.100(1.1)$ & $-214.000(1.7)^{* *}$ & $-227.000(2.3)^{*}$ \\
\hline$v_{14}^{13} b$ & $-.287(1.2)$ & $-.207(0.8)$ & $-.083(0.3)$ & $.006(0.2)$ & $-.296(1.1)$ & $-.110(0.4)$ & $.270(0.8)$ & $.285(0.8)$ \\
\hline$V_{15}^{n}$ & $.015(0.0)$ & $.276(0.3)$ & $.469(0.5)$ & $.777(0.9)$ & $.746(0.9)$ & $.985(1.1)$ & $.946(1.2)$ & $.777(1.0)$ \\
\hline$V_{16}^{15} b$ & $.294(0.4)$ & $.748(0.9)$ & $.243(0.3)$ & $.109(0.1)$ & $.454(0.6)$ & $.890(1.0)$ & $.493(0.6)$ & $.735(0.9)$ \\
\hline$V_{17}^{b}$ & $-.037(0.1)$ & $-.272(0.3)$ & $.593(0.6)$ & $.473(0.5)$ & $.306(0.3)$ & $-.147(0.2)$ & $.473(0.5)$ & $.183(0.2)$ \\
\hline$V_{18}{ }^{b}$ & $-.038(0.2)$ & $.516(2.0)^{*}$ & $-.223(0.9)$ & $.073(0.3)$ & $-.356(1.3)$ & $.144(0.5)$ & $-.812(3.5)^{*}$ & $-.175(0.8)$ \\
\hline $\mathrm{V}_{19}^{b}$ & $.513(0.3)$ & $-.761(0.4)$ & $.083(0.4)$ & $.090(0.1)$ & $-.219(0.1)$ & $-.253(0.1)$ & $-.408(0.2)$ & $-2.161(1.1)$ \\
\hline$v_{20}$ & $.023(0.6)$ & $.017(0.4)$ & $.047(1.0)$ & $.038(0.8)$ & $-.120(0.2)$ & $.030(0.6)$ & $.013(0.3)$ & $.017(0.4)$ \\
\hline$v_{21}^{b}$ & $.163(0.3)$ & $.053(0.1)$ & $-.223(0.4)$ & $-.102(0.2)$ & $.340(0.6)$ & $011(0.0)$ & $.118(0.2)$ & $.093(0.2)$ \\
\hline $\mathrm{V}_{22} b$ & $.001(1.0)$ & $.003(2.0)^{*}$ & $.001(0.7)$ & $.001(0.9)$ & $.002(1.4)$ & $.002(1.3)$ & $.003(1.9)^{* *}$ & $.005(3.4)^{*}$ \\
\hline u & $.033(0.7)$ & $-.016(0.3)$ & $.048(0.8)$ & $-.034(0.6)$ & $.078(1.3)$ & $.051(.08)$ & $.037(0.7)$ & $-.016(0.3)$ \\
\hline $\mathrm{R}^{2}$ & .040 & .154 & .063 & .103 & .105 & .122 & .222 & .259 \\
\hline $\mathrm{N}$ & 236 & 228 & 183 & 179 & 213 & 206 & 161 & 161 \\
\hline
\end{tabular}

${ }^{a}$ Coefficient has been multiplied by 100,000 .

bCoefficieńt has been multiplied by 100 .

*Coeffiriem is significant at the 05 level in a two-tailed test.

**Coefficient is significant al the .10 level in a two-lailed test.

Legend:

$S_{1}\left(S_{2}\right)$ The starting (maximum) salary for library professionals.

$S_{3}\left(S_{4}\right)$ The starting (maximum) salary for library technicians.

$S_{i_{1}}\left(S_{i}\right)$ The starting (maximum) salary for clerical employees.

$S_{7}\left(S_{x}\right)$ The starting (maximum) salary for maintenance employees.

All other variables are defined as in Table 1. 


\section{Table 3. Estimated Effects of Collective Bargaining Coverage on the Logarithms of Library Output Measures. \\ (absolute value $t$-statistics in parentheses)}

\begin{tabular}{|c|c|c|c|c|c|c|}
\hline $\begin{array}{l}\text { Output } \\
\text { Measures }\end{array}$ & $\begin{array}{c}\text { Model } \\
\text { Union Cities/ } \\
\text { Total Cities }\end{array}$ & (1) & (2) & (3) & (4) & (5) \\
\hline$Z_{1}$ & {$[73 / 213]$} & $.185(1.4)$ & .197 & .013 & $.118(0.8)$ & $.106(0.7)$ \\
\hline$Z_{2}$ & {$[83 / 252]$} & $.019(0.3)$ & .031 & .001 & $.053(0.8)$ & $.058(0.8)$ \\
\hline $\mathrm{z}_{3}^{-}$ & {$[83 / 255]$} & $.288(1.7)^{* *}$ & .399 & .376 & $.394(2.0)^{*}$ & $.390(2.0)^{*}$ \\
\hline$z_{1}$ & {$[84 / 256]$} & $-.048(1.0)$ & -.004 & .027 & $-.016(0.3)$ & $-.015(0.3)$ \\
\hline$Z_{5}$ & {$[66 / 215]$} & $.002(0.0)$ & .042 & .021 & $.032(0.5)$ & $.039(0.6)$ \\
\hline$Z_{6}$ & {$[82 / 251]$} & $.280(1.6)$ & .376 & .395 & $.354(1.7)^{* *}$ & $.346(1.7)^{* *}$ \\
\hline$Z_{i}$ & [83/252] & $-.059(0.9)$ & .029 & -.028 & $-.059(0.8)$ & $-.063(0.8)$ \\
\hline$Z_{8}$ & {$[65 / 211]$} & $-.010(0.2)$ & -.002 & -.038 & $-.025(0.3)$ & $-.022(0.3)$ \\
\hline
\end{tabular}

*Coefficient is significant at the .05 level in a two-tailed test.

**Coefficient is significant at the .10 level in a two-tailed test.

Legend:

$Z_{1}$ The number of information requests per capita.

$Z_{2} \quad$ The number of borrowers per capita.

$\mathrm{Z}_{3}$ The number of interlibrary loans per capita.

$z_{1}$ The total circulation per capita.

$Z_{5} \quad$ Book and periodical circulation per capita.

$Z_{i}$ The number of interlibrary loans per borrower.

$Z_{i}$ The total circulation per borrower.

$Z_{8} \quad$ Book circulation per borrower.

(1) OLS estimates for the entire sample, $(0,1)$ union variable included (from Table 1).

(2) OLS estimates done separately for union and nonunion samples; union differential evaluated at the mean values of the explanatory variables.

(3) Same as (2), except estimates have been corrected for selectivity bias.

(4) OLS estimates, sample of cities for which data on starting salaries for library clerical employees were available, $(0,1)$ union variable included.

(5) Same as (4), except the logarithm of clerical employees' wages has been included as an additional explanatory variable.

ences only the intercept terms in the wage and output equations; (2) estimating separate equations for unionized and nonunionized libraries; and then, on the basis of those estimates, (3) evaluating the differentials associated with collective bargaining at the mean values of the explanatory variables in the sample. These estimates suggest that this modification does not substantially alter any of the results. ${ }^{19}$

So far in our analysis, whether any of a library's employees are covered by a collec-

\footnotetext{
${ }^{19}$ The mean values of the explanatory variables are quite similar in the union and nonunion sectors. Hence, using the overall means in these calculations will not lead to any serious index-number problems. In other words, the estimates would not differ very much if either the mean values in the union sector or those in the nonunion sector were used.
}

tive bargaining agreement has been treated as exogenously determined. It is not unreasonable to expect, however, that collective bargaining coverage will be a function of both state laws governing public-employee unionization and the proportions of public and private employees in a state who are union members. The size of the library is also likely to matter: large libraries may be more bureaucratic in nature and more conducive to unionization. ${ }^{20}$ Finally, collective bargaining coverage is likely to be related both to the estimated wage premium associated with collective bargaining and to the estimated productivity differential

${ }^{20}$ Guyton, Unionization: The View of Librarians, pp. $126-34$. 


\section{Table 4. Estimated Effects of Collective Bargaining Coverage on the Logarithms of Library Employees' Annual Salaries.}

(absolute value $t$-statistic in parentheses)

\begin{tabular}{|c|c|c|c|c|}
\hline $\begin{array}{l}\text { Salary } \\
\text { Measure }\end{array}$ & $\begin{array}{c}\text { Model } \\
\text { Union Cities/Total Cities }\end{array}$ & (1) & (2) & (3) \\
\hline$S_{1}$ & [79/236] & $.033(0.7)$ & .034 & .081 \\
\hline S: & {$[79 / 228]$} & $-.016(0.3)$ & -.005 & .031 \\
\hline$S_{3}$ & {$[55 / 183]$} & $.048(0.8)$ & .055 & .020 \\
\hline$S_{1}$ & {$[56 / 179]$} & $-.034(0.6)$ & -.048 & -.078 \\
\hline$S_{:}$ & {$[76 / 213]$} & $.078(1.3)$ & .072 & .114 \\
\hline$S_{i i}$ & {$[74 / 206]$} & $.051(0.8)$ & .040 & .080 \\
\hline$S_{i}$ & {$[48 / 161]$} & $.037(0.7)$ & -.076 & -.105 \\
\hline$S_{s}$ & {$[49 / 161]$} & $-.015(0.3)$ & -.119 & -.143 \\
\hline
\end{tabular}

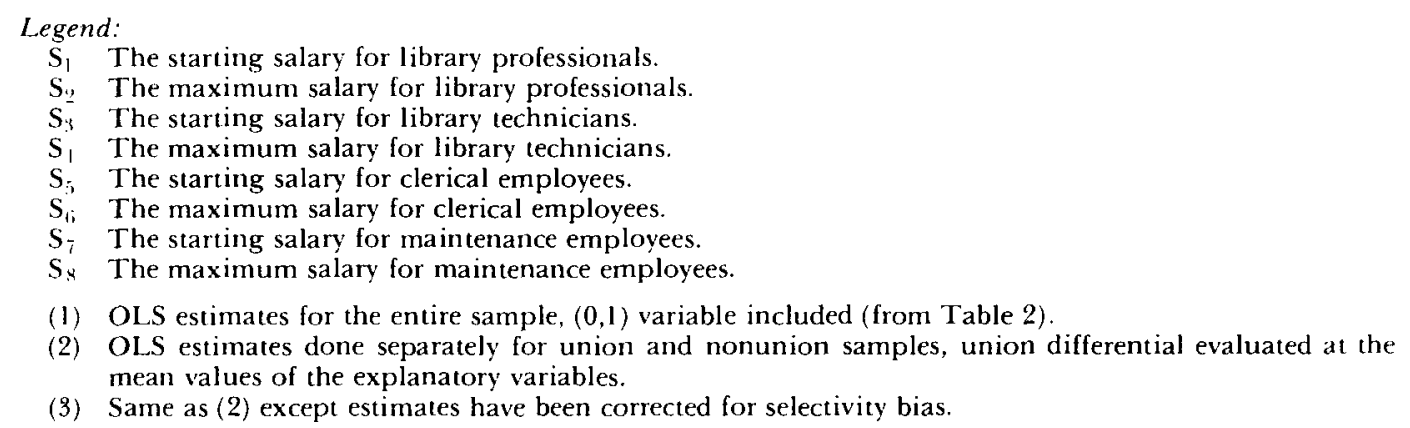

associated with collective bargainingthe former because it influences both employees' demand for collective bargaining coverage and library management's resistance to it, the latter because the productivity effects associated with collective bargaining also influence management's resistance to it.

As is well known, estimates obtained using ordinary least squares (OLS) techniques with observed wage or productivity data, such as those presented in Tables $l$ and 2 , may be subject to selectivity bias. In other words, the estimates will be inconsistent if the error terms in the wage or productivity equations are correlated with whether the library is covered by a collective bargaining agreement. If libraries are not randomly assigned to collective bargaining status, the estimated coefficients of the wage or productivity equations within a sector (union or nonunion) may be capturing the effect of an explanatory variable on whether the library is covered by a collective bargaining agreement, as well as the effect of the variable on the outcome of interest (wages or productivity). The problem is thus analagous to an "omitted variable" problem, where the omitted variable in the wage and productivity equations is the probability that a library is covered by a collective bargaining agreement.

Fortunately, there is an econometric technique that can resolve this problem. ${ }^{21}$

\footnotetext{
${ }^{21}$ For the genesis of this approach, see James J. Heckman, "Sample Selection Bias as a Specification Error," Econometrica, Vol. 47, No. 1 (January 1979), pp. 153-61 and Lung-Fei Lee, "Unionism and Wage Rates: A Simultaneous Equations Model With Qualitative and Limited Dependent Variables," International Economic Review, Vol. 19, No. I (June 1978), pp. 415-33. A very readable discussion of the selection bias problem is presented in Gregory M. Duncan and Duane E. Leigh, "Wage Determination in the Union and Nonunion Sectors: A Sample Selectivity A pproach," Industrial and Labor Relations Review, Vol. 34, No. 1 (October 1980), pp. 24-34. An appendix spelling out the details of this problem in the context of this research is available from the authors upon request.
} 
A reduced-form, probit equation, in which library employees' wages and library output are replaced by their determinants, can first be estimated to determine the probability that a library's employees are covered by a collective bargaining agreement; the explanatory variables in this equation should include all those that directly influence the probability of collective bargaining coverage, as well as those that influence the wage and productivity differentials associated with collective bargaining. From this equation, one can compute estimates of variables that are then added to the productivity and wage equations to control for the probability that a library's employees are covered by a collective bargaining agreement. Consistent parameter estimates can then be obtained by estimating by OLS techniques these "augmented" output and wage equations; this can be done separately for libraries that are covered by a collective bargaining agreement and those that are not. Finally, the estimated parameters and the mean values of the explanatory variables can be used to compute consistent estimates of the union/nonunion output and wage differentials.

Estimates of the reduced-form, probit equation are displayed in Table 5. Column 1 includes only those variables that are expected to influence the probability of collective bargaining coverage directly, while column 2 includes, in addition, those variables that enter the equation indirectly through their postulated effects on the union/nonunion wage and output differentials. Quite strikingly, a number of the former set of variables prove to be statistically significant. In particular, the probability of observing a library's employees covered by a collective bargaining agreement is higher in states where local-government employees are more heavily unionized $\left(V_{4}\right)$, in states where mediation or factfinding services are provided by state agencies to assist local-government bargaining $\left(V_{9}\right)$, and in large cities $\left(V_{10}\right)$, whereas the probability is lower in states where municipal-employee strikes are illegal $\left(V_{8}\right) \cdot{ }^{22}$

\footnotetext{
${ }^{22}$ We are grateful to our colleague John Burton for providing us with the data he has collected on the
}

Table 5. Probit Estimates of the Determinants of Collective Bargaining Coverage for Library Employees. (absolute value, asymptotic $t$-statistics in parentheses )

\begin{tabular}{|c|c|c|}
\hline Variable & (l) & (2) \\
\hline $\mathrm{C}$ & $2.460(3.7)^{*}$ & $1.820(0.3)$ \\
\hline$V_{1}$ & $-.712(1.7)^{* *}$ & $-.664(1.5)$ \\
\hline $\mathrm{V}_{2}{ }^{a}$ & $-.072(1.6)$ & $.004(0.1)$ \\
\hline$V_{3}$ & $-.008(0.8)$ & $-.011(1.1)$ \\
\hline $\mathrm{V}_{1}$ & $.028(1.6)$ & $.032(1.8)^{* *}$ \\
\hline$V_{i}$ & $.023(1.0)$ & $.029(1.2)$ \\
\hline$V_{i}$ & $-.437(0.6)$ & $-.181(0.2)$ \\
\hline $\mathrm{V}_{i}$ & $.379(1.0)$ & $.387(0.9)$ \\
\hline$v_{*}$ & $-.943(4.0)^{*}$ & $-1.250(4.2)^{*}$ \\
\hline$V_{!}$ & $1.370(3.0)^{*}$ & $1.480(2.8)^{*}$ \\
\hline$V_{10}{ }^{a}$ & $.508(3.1)^{*}$ & $.388(1.8)^{*}$ \\
\hline$V_{11}$ & & $-.076(0.3)$ \\
\hline$V_{12}$ & & $.224(1.9)^{*}$ \\
\hline$v_{13} a$ & & $.037(0.1)$ \\
\hline$V_{11}$ & & $-.786(0.6)$ \\
\hline $\mathbf{V}_{1: 5}$ & & $.838(0.2)$ \\
\hline$V_{16 i}$ & & $-.044(1.3)$ \\
\hline$V_{17}$ & & $.071(1.7)^{* *}$ \\
\hline$V_{1 R}$ & & $-.025(1.8)^{* *}$ \\
\hline$V_{1 ! 1}$ & & $.002(0.0)$ \\
\hline$V_{201}$ & & $-.169(0.9)$ \\
\hline$V_{21}$ & & $.043(1.6)$ \\
\hline$v_{29} a$ & & $-.285(0.0)$ \\
\hline $\begin{array}{l}\text { Number of } \\
\text { Observations } \\
\text { Fraction }\end{array}$ & 260.0 & 256.0 \\
\hline Organized & .327 & .328 \\
\hline $\begin{array}{l}\text { Log Likelihood } \\
\chi^{2}\end{array}$ & $\begin{array}{r}-110.8 \\
107.0\end{array}$ & $\begin{array}{r}-102.6 \\
118.9\end{array}$ \\
\hline
\end{tabular}

$$
\begin{aligned}
& { }^{a} \text { Coefficient has been multiplied by } 100,000 \text {. } \\
& \text { Legend: } \\
& V_{2} \quad \text { The number of volumes in library. } \\
& V_{3} \quad \text { The percent of state government employ- }
\end{aligned}
$$

All other variables are defined as in Table 1. 
Armed with the probit estimates from column 2, one can proceed as described above to compute the estimated union/nonunion output and wage differentials for the various measures; this is done in columns 3 of Tables 3 and 4, respectively. A comparison of columns 2 and 3 of each of these tables suggests that although the probability of collective bargaining coverage is endogenously determined, selectivity bias does not appear to be an important problem. In most cases, the estimated differentials do not appear to be sensitive to the correction for selectivity bias; most are similar in magnitude to those reported in the previous columns.

Finally, the estimates obtained so far of the effects of collective bargaining on output capture both the net effect of unions on the production function for library services and the effect of union-induced wage gains on average costs and, hence, output. Although the estimates in Table 4 suggest that union-induced wage effects are insignificant, no direct estimates of union effects on the production function or on the demand for library services have been obtained. To do so would require including a measure of library employees' wages in the library output equation (see Equation 6). ${ }^{23}$ The wage measure we choose to use is the starting salary for library clerical employees $\left(S_{5}\right)$; this measure is available for a large number of cities and is the only wage measure for which the union/nonunion differential is close to statistically significant (Table 4).

Column 4 of Table 3 replicates the estimated union/nonunion output differentials reported in column 1 for a subsample of cities for which the clerical wage variable was available: the estimates are quite similar. Column 5 in Table 3 indicates the estimated differentials when the clerical wage is included as an additional explanatory variable. As is evident, the inclusion of the wage variable does not alter any of our conclusions. The only library output measure

\footnotetext{
characteristics of state bargaining laws covering municipal employees in 1977.

${ }^{23}$ See footnote 12 for an explanation of why wages were initially excluded from the equation.
}

that is significantly associated with collective bargaining coverage is the number of interlibrary loans.

\section{Direct Estimates of Production Functions}

Instead of focusing on the effect of collective bargaining coverage on observed output, an effect determined by both demand and cost considerations, one can focus directly on the underlying production process for library services. For example, if the production function in Equation 2 is CobbDouglas, one can specify the following equation:

$$
Q=A(1+B u) L^{\alpha_{1}} K^{\alpha_{2}},
$$

where $u$ equals one if the library is unionized and zero if otherwise, and $B$ represents the proportionate productivity differential of unionized libraries. $B$ thus indicates the proportion by which a unionized library's output would exceed the output of an otherwise identical nonunion library.

Equation 8 implies that:

$$
\begin{gathered}
\log Q=\log A+\alpha_{1} \log L \\
+\alpha_{2} \log K+B u .
\end{gathered}
$$

Hence, regressing the log of output on (1) those demographic variables that affect library productivity (variables that underlie $A$, such as population density or city size), (2) the logarithms of capital and labor, and (3) a measure of whether the library is organized would enable one to estimate the proportionate productivity advantage of unionized libraries. ${ }^{24}$

The results of estimating Equation 9 with five measures of library output are summarized in Table 6, which reports the coefficient of the collective bargaining variable for a number of different specifications. ${ }^{25}$ Rows I through 6 aggregate the various occupational categories of library employees into a single measure by first assum-

\footnotetext{
${ }^{24}$ See Brown and Medoff, "Trade Unions in the Production Process, " for a similar approach applied to the private sector.

${ }^{25}$ The number of libraries included in the analysis reported in Table 6 is substantially smaller than those reported in the previous tables because of the limited number of libraries that reported the necessary employment data.
} 


\section{Table 6. Estimated Effects of Collective Bargaining Coverage on the Logarithms of Library Output Measures: Cobb-Douglas Production Function Approach. (absolute value $t$-statistics in parentheses)}

\begin{tabular}{|c|c|c|c|c|c|}
\hline \multirow[b]{2}{*}{ Model } & \multicolumn{5}{|c|}{ Output Measures (sample sizes in brackets) } \\
\hline & $Q_{1}[104]$ & $Q_{2}[107]$ & $Q_{3}[97]$ & $Q_{4}[107]$ & $Q_{5}[93]$ \\
\hline $\begin{array}{l}(1) \\
(2) \\
(3)\end{array}$ & $-.085(0.8)$ & $\begin{array}{l}.523(2.0)^{*} \\
.552 \\
.549\end{array}$ & $.181(0.9)$ & $-.065(0.8)$ & $-.095(1.1)$ \\
\hline $\begin{array}{l}(4) \\
(5) \\
(6)\end{array}$ & $-.088(0.8)$ & $\begin{array}{l}.519(2.0)^{*} \\
.553 \\
.550\end{array}$ & $.176(0.9)$ & $-.069(0.8)$ & $-.098(1.1)$ \\
\hline $\begin{array}{l}(7) \\
(8)\end{array}$ & $\begin{array}{l}-.128(1.0) \\
-.127(1.0)\end{array}$ & $\begin{array}{l}.841(2.7)^{*} \\
.842(2.7)^{*}\end{array}$ & $\begin{array}{l}.003(0.0) \\
.007(0.0)\end{array}$ & $\begin{array}{l}-.072(0.8) \\
-.070(0.8)\end{array}$ & $\begin{array}{l}-.077(0.9) \\
-.075(0.9)\end{array}$ \\
\hline
\end{tabular}

*Coefficient is significant at the .05 level in a two-tailed test.

Legend:

$Q_{1}$ The number of borrowers.

Q. The number of interlibrary loans.

$\mathbf{Q}_{3}^{-}$The number of information requests.

$Q$ The total circulation.

$Q_{5}$ Book circulation.

(1) Cobb-Douglas model with single labor input: the number of full-time-equivalent library professionals, which is computed by assuming that all categories of library employees have infinitely elastic elasticities of substitution and then counting each part-time employee as one-half of a fulltime employee and weighting each category's employment by the mean (in the sample) ratio of its starting salary to the starting salary of library professionals. The collective bargaining variable shifts the intercept term.

(2) Same as (1), but separate equations are estimated for the union and nonunion sectors, and the diferential is then evaluated at the mean values (in the sample) of the explanatory variables.

(3) Same as (2), except the estimates have been corrected for selectivity bias.

(4),(5),(6) Same as (1), (2), and (3), respectively, except maximum salaries rather than minimum salaries are used to weight the different occupations.

(7).(8) Same as (1) and (4), respectively, but multiple labor inputs: professionals, library technicians, clerical, and maintenance. Professionals were formed by aggregating head librarians, library professionals, and other professionals in the manner described in (1). This assumes that the different professional categories have elasticities of substitution that are infinite for each other, but that across the four major occupational categories-professional, technician, maintenance, clericalthe elasticity of substitution is unity.

ing that all categories have infinitely elastic elasticities of substitution for one another, and then weighting each category by its mean (in the sample) relative salary and counting each part-time employee as onehalf of a full-time employee. Rows 7 and 8 use a multiple labor-input generalization of Equation 9; this allows the elasticity of substitution to be unity across aggregated categories but to be infinite across the detailed occupational groups within a category.

Some of the models summarized in Table 6 allow the collective bargaining variable to affect only the intercept term (as in Equation 9). Others estimate separate equations for the union and nonunion sectors (allowing all of the coefficients to vary with union status) and then evaluate the union/nonunion differential at the mean of the explanatory variables in the sample. Finally, some are estimated using the model that treats collective bargaining coverage as endogenous and corrects for selectivity bias, as discussed in the previous section. In all cases, the results are virtually identical to those discussed in that section. Although 
collective bargaining coverage is positively associated with the number of interlibrary loans, other things equal, neither the number of borrowers nor the library's circulation of books and other materials is related to collective bargaining coverage. ${ }^{26}$

The production-function approach to estimating the effects of unions on productivity in the public sector is more direct than the first approach described and thus might seem to be preferable. Such an approach, however, requires the researcher to have data on full-time and part-time employment levels of various categories of public employees and to make assumptions about the elasticities of substitution among different labor inputs. As noted in Table 6 , the lack of the necessary employment data reduced our sample sizes to roughly 100 observations when we used this approach. Because of these problems, many researchers may find the indirect approach to be preferable.

\section{Concluding Remarks}

This paper has presented two analytic frameworks that can be used to analyze the effects of collective bargaining on productivity in the public sector. The first involves estimating reduced-form output equations, based on a model of the equilibrium level of public services in a community. The second involves direct estimation of public sector production functions. Both frameworks

\footnotetext{
${ }^{26}$ Two alternative specifications warrant mention here. We relaxed the assumption of a Cobb-Douglas technology and attempted to ascertain if collective bargaining coverage affects the elasticity of substitution between capital and labor (using a CES production function) or the elasticities of substitution among different categories of library employees (using a translog cost function). Neither of these alternative approaches indicated any significant relationships between collective bargaining coverage and the elasticities of substitution. For a discussion of how unionization affects elasticities of substitution in the private sector, see Richard B. Freeman and James L. Medoff, "Substitution Between Production Labor and Other Inputs in Unionized and Nonunionized Manufacturing," Review of Economics and Statistics, Vol. 64, No. 2 (May 1982), pp. 220-33.
}

allow for the treatment of collective bargaining coverage as endogenous and for controls for selectivity bias.

The frameworks were illustrated using cross-section data for a sample of 256 municipal libraries in 1977. The estimates obtained suggest that collective bargaining coverage for library employees is not associated with higher wage rates or with higher (or lower) levels of library circulation and borrowers. Both approaches do suggest, however, that the number of interlibrary loans is larger in unionized libraries. Since this category of library output is not a major one, collective bargaining coverage, on balance, does not appear to affect significantly library output or library employees' wages. Our estimates also suggest that both the overall level of local-government unionization in a state and the state's laws governing collective bargaining in local government are significant determinants of whether any given muxisipal library is organized.

Although output measures are often difficult to quantify for other local-government functions, our approaches, in principle, can be implemented for a variety of functions, including those in which public sector unions might, a priori, be expected to have larger effects (education, police, firefighters, and sanitation, for example). The approaches could also be extended by using longitudinal data to ascertain the extent to which changes in collective bargaining status are associated with changes in employee productivity. ${ }^{27}$ Finally, with suitable data on the provisions of collective bargaining agreements, rather than data on their mere existence, one could attempt to trace the routes by which unions influence productivity in the public sector; that is, one could attempt to ascertain directly how grievance resolution procedures, the role of seniority in layoffs and promotions, and restrictive work rules affect productivity.

\footnotetext{
${ }^{27}$ See Clark, "The Impact of Unionization on Productivity: A Case Study," for an application of this approach to the private sector.
} 